\title{
Analysis of Sharia Compliance in the Implementation of Hajj Saving Product
}

\author{
Sulvariany Tamburaka, Nitri Mirosea*, Hendriawan \\ Universitas Halu Oleo, Kampus Hijau Bumi Tridharma, Anduonohu, Kec. Kambu, Kota Kendari, Sulawesi Tenggara 93232, Indonesia \\ *nitri.mirosea@uho.ac.id
}

ARTICLE INFO

Article history

Received 15 December 2020

Revised 30 March 2021

Accepted 23 April 202

Keywords

Hajj funds;

Hajj Pilgrimage;

Saving products;

Sharia Compliance.

\section{ABSTRACT}

This study aims to investigate the implementation of sharia compliance of a hajj saving product. The data analysis method used was descriptive analysis with quantitative approach. The data collection method employed was open questionnaire and documentation. The result shows that Hajj saving product of BNI Baitullah IB Hasanah was in accordance to guideline of Syariah principles namely: Justice, Balance (al 'adl wa tawazzun), Security (al maslahah), Universalism, and free of gharar and riba. Hajj saving of BNI Baitullah IB Hasanah is based on two agreements namely (1)wadiah yad dhamanah which means that the form of depositing funds between the owner of the fund and the recipient of the deposit that is trusted to safeguard the funds; and secondly (2) mudharabah mutlaqah, which is an agreement between capital owners and the bank whereas the funds deposited in the bank is managed and distributed to those who needs fund.

This is an open access article under the CC-BY-SA license

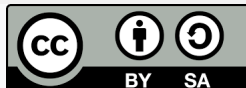

\section{Introduction}

Indonesia is one of the countries where the majority of the population is Muslim. Some obligations are fulfilled by the Muslims in the five pillars of Islamic rule, one of which is pilgrimage. Hajj means intentionally or well planned visit to the Ka'bah in Makkah to perform Hajj. Hajj is a religious ritual performed by Muslims to finalize into perfect worship in the name of Allah SWT. However, over time the essence of the pilgrimage is no longer only included in the scope of worship to Allah alone but experienced a shift in meaning by involving muamalah in it. Muamalah means interaction between human being in society based on Sharia law. Hajj pilgrimage as seen as two sides; firstly as a religious journey as a Muslim and; secondly as business opportunity to broaden the meaning of pure religious worship and also muamalah side.

The cost of Hajj pilgrimage is considered costly due to (1) flight fare depends on the origin countries to, and (2) staying cost in Makkah during hajj trip. Performing hajj is an obligation to all Muslim with two basic conditions: they must be physically and financially able. The high cost of hajj for muslims requires those who are willing to save money in long term for hajj pilgrimage.

Sharia Bank offers hajj savings product services so that the management of hajj funds is avoided from the practice of usury, maysir and gharar. In this way, hajj as a religious ritual can run according to sharia principles. The development of Islamic 
financial institutions, especially Islamic banking, makes people prefer hajj savings in Islamic Banks that are trusted in managing Hajj funds, which opens hajj savings in Islamic Banks, since it does not use the conventional interest system and is in accordance with Islamic principles [1].

Sharia compliance is the core of the integrity and credibility of Islamic banks that guarantees the fulfillment of the implementation of Islamic principles as a whole ( $\mathrm{kaffah}$ ) both in the collection, management and distribution of Islamic banks [2]. Potential irregularities in Sharia banks that are often questioned and cause public doubt in the Sharia banking system are the accordance of bank operations with the rules or compliance with Islamic Sharia. In general, the public still has difficulty differentiating between contracts in Islamic banks and transactions at conventional banks. As a result, the public considers that there is no difference between Islamic banks and conventional banks.

The difference between theory and practice in Islamic banking makes the report or opinion of the Sharia Supervisory Board that is attached to the financial statements of the Islamic Bank unable to convince the public of the true nature of Islamic bank. This is due to the understanding of products, as well as terms from Islamic finance and banking which are still low, in addition to the quality and quantity of the human resources of Islamic Banks in understanding the principles of Islamic muamalah. BNI Syariah Bank is one of the Recipients of Hajj Pilgrimage-Fee Management (BPS-BPIH), known as Baitullah IB Hasanah products. BNI Baitullah IB Hasanah is calssified as savings with mudharabah and wadiah agreements that are used as a means of planning the pilgrimage according to the wishes of savers with a free or monthly deposit system in Rupiah or USD. This research aims to analyse the implementation of sharia compliance in the management of the Hajj Savings Fund at BNI Syariah KC Kendari. The novelty of this research lies on the contextuality of research as it employed qualitative approach.

\section{Method}

This study is intended to determine and analyze the application of sharia compliance (Shariah compliance) on BNI Baitullah IB Hasanah Hajj savings products. To assess the application of sharia compliance on BNI Baitullah IB Hasanah Hajj savings products that have been implemented well, a measure or method based on DSN-MUI Fatwa Number 02 / DSN-MUI / 1V / 2000 on Savings and a review of sharia principles is based provisions of article 2 paragraph (3) of Bank Indonesia Regulation Number 10/6/2008 concerning the implementation of sharia principles in the collection, distribution of funds and Islamic bank services.-The object used by the author in this study is the Application of Sharia Compliance in BNI Baitullah IB Hasanah Hajj Savings Products. This type of research is qualitative research, namely data in the form of sentences, words or images [3]. In this study, qualitative data in the form of information both oral and written relating to this study were collected.

Data collection methods used in this study are conducting interviews and documentation to informants who are considered to understand the problem under study. They comprise data collected by recording or copying existing data at the BNI Syariah KC Kendari Bank in the form of a profile, structure and description of the main tasks of each division, and so on. Data was also collected in the form of interview to the parties directly related and competent with the problem. Ms. Aisyah, the Operational Head Manager of Bank BNI Syariah KC Kendari was the most suitable informant for this research. 
Analysis of the data used by the writer is descriptive analysis, which is an analysis that explains the application of sharia compliance to the hajj savings product at BNI Syariah KC Bank Kendari. The results of the analysis are then interpreted in order to provide a clear picture of the proposed problem.

\section{Results and Discussions}

\subsection{Sharia Enterprise Theory}

Sharia Enterprise Theory (SET) according to is a theory that places God as the center of everything. God is the return of man and the universe [4]. Humans as their representatives (khalifatullah fil ardh) have consequences that obey all the laws of God. Human compliance solely is imperative in order to return to God with a calm soul. The process of returning to God requires a process of self-union with fellow humans and nature as well as the godly laws inherent in it.

God is the highest position and is the only ultimate goal for human life. By placing God as the highest stakeholder in accounting, a link between Islam and the economy will be established. The economic system as well as accounting reports will then aim at "arousing the divine awareness" of its users. With this, it is expected that there are no human actions that can harm themselves or others because of their compliance to God's commands. In the Sharia Enterprise Theory, God is the main trustee, while the resources owned by the stakeholders are trusted from God, which is inherent in a responsibility to be used in the manner and purpose set by God.

\subsection{Concept of Sharia Compliance}

Based on Bank Indonesia Regulation Number 13/2/PBI/2011 concerning the Implementation of Compliance Functions of Commercial Banks, the definition of compliance is the value, behavior, and actions that support the creation of compliance with Bank Indonesia regulations and applicable laws and regulations, including sharia principles for Sharia Commercial Bank (BUS) and Sharia Business Unit (UUS) [5].

The meaning of sharia compliance in sharia banks is the application of Islamic, sharia principles and traditions in financial and banking transactions in general and other related businesses [6]. In addition, some have also suggested that sharia compliance is one indicator of Islamic disclosure to ensure sharia bank compliance with sharia principles [7]. The meaning of operational sharia compliance refers to the compliance with the National Sharia Council Fatwa Council Indonesian Ulama (DSN-MUI), which is an embodiment of sharia principles and rules that must be adhered to in sharia banking.

As a manifestation of the fulfillment of all sharia principles, sharia financial institutions must have characteristics, integrity and credibility in complying Islamic laws. The compliance comprises the values, behaviors and actions that support the creation of sharia bank compliance with sharia principles. The National Sharia Council (DSN-MUI) fatwa and Bank Indonesia Regulation (PBI) have become the measures of compliance with sharia principles, both in products, transactions and operations in Islamic banks. Sharia compliance is consistently used as a framework for the system and finance of Islamic banks in the allocation of resources, management, products, capital market activities, and wealth distribution.

Sharia Compliance has a legal basis, namely the provisions of Article 2 paragraph (3) PBI No. 10/6/2008 (amendments to PBI No. 9/19/PBI/2007) concerning the implementation of sharia principles in fund raising and distribution of funds and sharia 
bank services, the fulfillment of sharia principles is carried out by complying with Islamic basic provisions including principles of justice and balance ('adl wa tawazun), benefit (maslahah), and universalism (naturalyah) and avoidance to gharar, maysir, and usury.

\subsection{Role of the DSN-MUI Fatwa on Sharia Compliance}

DSN-MUI was formed in order to realize the aspirations of Muslims regarding economic problems and encourage the application of Islamic teachings in the economic/ financial sector which is carried out in accordance with Islamic Sharia demands. Fatwas issued by DSN-MUI are not positive laws, just like fatwas issued by MUI in other fields. In order that the fatwas issued by DSN-MUI can be valid and binding as positive law applies in Indonesia, then Law No.21 of 2008 concerning Sharia Banking states that fatwas issued by DSN-MUI can be followed up as Bank Regulations Indonesia.

\subsection{Definition of Sharia Bank}

Law No. 21 of 2008 concerning sharia banking and sharia banks explains that sharia banking is everything related to sharia banks and sharia business units, including institutions, business activities and procedures and processes in carrying out their business activities according to sharia principles. Sharia Banks are banks that carry out their business activities based on sharia principles and by type of sharia banks consist of BUS (Sharia Commercial Banks), UUS (Sharia Business Units) and BPRS (Sharia Rural Financing Banks).

Islamic banks were established with the aim of promoting and developing Islamic traditional principles in financial and banking transactions and other related businesses. Islamic banks or hereinafter referred to as sharia banks are banks that operate without relying on interest or in other words Islamic banks are financial institutions whose principal business is providing financing and other services in payment traffic and the circulation of money whose operations are adjusted to Islamic principles.

\subsection{Legal Basis for Sharia Banking Savings for Hajj in Indonesia}

Mudharabah hajj savings are deposits of third parties who can only be withdrawn at the time the customer will perform the pilgrimage [8]. This savings is a savings by getting a yield. Based on the DSN-MUI Fatwa No.02/ DSN-MUI/ IV/2000, savings that are sharia justified are savings based on mudharabah and wadiah principles [9], with the following conditions. First, adherence to general provisions based on the mudharabah principle. In this transaction the customer acts as shahibul maal or the owner of the funds and the bank acts as the mudharib or fund manager. In its capacity as a mudharib, a bank can carry out a variety of businesses that do not conflict with the principles of shari'ah and develop them, including mudharaba with other parties. Capital must be stated in amount, in cash and not receivables. Profit distribution must be stated in the form of a ratio and stated in the account opening agreement. The bank as a mudharib covers the operational costs of savings by using the profit ratio to which it is entitled. Banks are not permitted to reduce customer profit ratios without the relevant consent.

Second, general provisions based on the wadiah principle. Savings are deposits that can be taken at any time (on call) or by agreement. No reward is required, except in the form of voluntary ('athaya) gifts from the bank.

Hajj savings are savings plans for customers to perform the Hajj by investing funds gradually in financial institutions (in this case Islamic banks) or other forms of investment. Hajj savings is a form of banking service that aims to make it easier for people to plan savings for going on Hajj. Islamic banks as a sharia-based financial institution seeks to 
raise funds for people who want to go on pilgrimage, providing some form of shariacompliant services both in terms of contracts and other operational forms.

\subsection{Hajj Savings Products at Bank BNI Syariah KC Kendari}

BNI Baitullah IB Hasanah is a product of funds in the form of hajj savings by BNI Syariah KC Kendari. Based on the results of interviews conducted, this savings were described as follows: hajj savings products at BNI Syariah are BNI Baitullah IB Hasanah savings. There are two hajj savings accounts in Bank BNI Syariah KC Kendari, namely the wadiah contract and the mudharabah agreement. The contract is the same as the use of the contract for several other types of savings such as business savings, IB Prima Hasanah Savings, and several other types of savings at BNI Syariah KC Kendari. Both contracts also apply to deposits and demand deposits. The Hajj savings can be auto-credited. For example, a customer who has other savings in BNI Syariah such as IB Hasanah savings, business savings and so on that can be credited monthly, may ask certain amount to be transferred to a hajj savings account. Cash payment is also accepted. Both savings are equal in terms of the principles and conditions, except for the amount of funds deposited and the waiting period for hajj pilgrimage. If payment made is Rp25 million, there will be a waiting period of 10-12 years, while if payment made is above Rp40 million, there will be a waiting period of $4-5$ years.

Based on the results of the interview it can be concluded that the BNI Hajj Savings Baitullah IB Hasanah at BNI Syariah KC Kendari Bank is treated the same as several other types of savings in terms of the use of the contract used in the collection of funds, namely the wadiah contract and mudharabah contract. Explanation about the process to open a BNI Hajj savings account in BNI Syariah KC Kendari Bank is explicated in this interview: "...opening a hajj saving is done like opening an ordinary savings account, the customer comes to customer service and then expresses his desire to open a hajj savings account by submitting or showing identity originals such as ID cards and other requirements that are met then the customer makes a minimum initial deposit of Rp100,000 for the wadiah contract and Rp500,000 for mudharabah agreements. However, if customers want to immediately get the portion number of hajj, he/she can directly deposit Rp25 million for regular savings and Rp40 million for hajj savings plus as mentioned earlier ". (Interview on 28 February 2019).

Based on the interview information and the documentation, it can be concluded that the BNI Syariah KC Kendari Bank is one of the Hajj Pilgrimage Receiving Banks (BPS-BPIH) that provides hajj savings services and is directly connected to the real time online Integrated Hajj Computerized System (SISKOHAT) Ministry of Religion. The BNI Baitullah IB Hasanah Hajj savings product is a medium to facilitate a Muslim community that is materially capable to invest the funds they have for planning the departure of the pilgrimage, so that it is no longer just a plan but can be realized.

\subsection{Management of Hajj Savings Fund at Bank BNI Syariah KC Kendari}

The BNI Baitullah IB Hasanah Hajj savings product is one of the fundraising products at the BNI Syariah Syariah Bank that uses the Wadiah contract and the Easyarabah contract when opening an account where funds collected from this type of savings are treated as productive funds and used for operational needs at BNI Syariah Bank KC Kendari. Ms. Aisyah, the Offfice Head of BNI Syariah KC Kendari stated: 
"so when opening an account we give an option to prospective Hajj savings customers BNI Baitullah IB Hasanah ie. if a customer uses a wadiah contract, the contract specimen has explained that the customer only entrusts funds to meet the minimum cost of pilgrimage $(\mathrm{ONH})$ and the customer does not provide certain requirements to the bank related to the use of savings funds. If the customer chooses the option to use the mudharabah agreement, the contract specimen states that the hajj savings customer will receive a profit sharing on funds saved during the waiting period to obtain a portion of the departure from the Ministry of Religion namely a 5\% ratio for the customer and $95 \%$ for the bank. BNI Syariah Bank is the only bank that uses these two contracts as an option for prospective customers and this is also one of the marketing strategies that we do and the other advantages offered here are that there are no administrative fees at all. " (Interview on 28 February 2019).

The management of the Hajj savings fund system at BNI Syariah KC Kendari can be concluded was in accordance with sharia compliance when viewed from a fund collection system based on the DSN-MUI Fatwa Number 02/DSN-MUI/IV/2000 concerning savings namely using wadiah contract and mudharabah agreement. This is also in line with the principle of universalism whereby the Hajj savings customer entrusts the bank to manage the funds it holds for the operational needs of the bank without certain conditions for the management of its savings funds.

The contract used in relation to the BNI Hajj Savings BNI Baitullah IB Hasanah fund management system at the BNI Syariah KC Kendari Bank is the mudharabah mutlaqah agreement as explained by Ms. Aisyah in the interview as follows:

"The type of contract used in the governance system of the use of the hajj savings fund is the mudharabah mutlaqah contract. This was done to simplify the managerial system in managing funds as well because the free rights obtained by banks to the use of customer funds both from the agreement through the wadiah contract specimen and from the mudharabah contract. Actually the funds raised from the pilgrimage savings are not funds that are silent and indeed must be managed so that the bank chooses to use mudharabah mutlaqah, therefore there will be profit sharing ratio. " (Interview on 28 February 2019).

Based on the results of the interview, we concluded that the management of the Hajj savings fund at BNI Syariah KC Kendari Bank was in accordance with sharia compliance when viewed from the mudharabah contract provisions based on the DSN-MUI Fatwa Number 02 / DSN-MUI / IV / 2000 concerning savings where BNI Syariah Bank as mudharib acts as an investment manager and has the right to conduct business activities according to the strategies and policies applied. The BNI Baitullah IB Hasanah Hajj savings fund management system was described by Ms. Aisyah as follows:

"...the management of the BNI Baitullah IB Hasanah Hajj Savings fund is included in the pooling system, namely the Hajj savings fund combined with all funds from current accounts, savings and deposits made into one in a centralized system then channeled to financing, such as mudharabah, musharaka, and various other fund distribution products. This also makes BNI Syariah Bank use the mudharabah mutlaqah contract for this type of product to make it easier for the system to manage funds from these various products. " (Interview on 28 February 2019). 
This method is a mechanism of implementing the performance of Bank BNI Syariah KC Kendari in managing funds collected from the community as a benchmark in generating and developing revenue for the operational development of BNI Syariah Bank. The benefits of managing the hajj savings fund at BNI Syariah Bank are then channeled back to the hajj savings account holder based on the nominal value of the savings as the results of the interview as follows: the benefits of managing our hajj savings funds are shared with each of the savings account holders based on the nominal value in the account the customer. For customers who use mudharabah contracts, the profit sharing is in accordance with the agreement in the contract, which is 5\%: $95 \%$, and for customers who use the wadiah agreement.

"Regarding determining how much is the profit sharing ratio per month, we use equivalent rate. The equivalent rate is the profit sharing percentage divided by the average customer account balance per month expressed as a percentage. And the percentage for the equivalent rate per month can be seen on the profit sharing ratio printed on the customer information system and it applies to all customers including the owner of the BNI Hajj Baitullah IB Hasanah savings account. " (Interview on 28 February 2019).

Based on the results of the interview, it can be concluded that the provision of profit sharing ratios from the management of BNI Hajj Baitullah IB Hasanah at BNI Syariah KC Bank Kendari was in accordance with Sharia Compliance as viewed from the principle of benefit (al mashlahah) that the distribution of profits from the results of operating profits used the principle for net revenue sharing by setting the ratio agreed in the contract at the time of opening the Hajj savings account.

Customers who have BNI Baitullah IB Hasanah Hajj savings account using mudharabah agreement will continue to receive profit sharing distribution over the waiting period as explained further by Ms. Aisyah:

"BNI Baitullah IB Hasanah Hajj savings account owner who uses mudharabah agreement will continue to get the distribution of profit sharing as stated in contract specimens used during the expiration of the waiting period and the closing of the account after the pilgrimage. After depositing funds in the customer's account reaches Rp25,500,000, then Bank BNI Syariah can deposit funds in the amount of Rp25,000,000 to SISKOHAT online according to the provisions set by the Ministry of Religion. As is known, after getting the funds deposited for the portion numbers carried out does not necessarily mean the Baitullah IB Hasanah Hajj savings account ends. Because there will be repayments that must be deposited by customers in accordance with a Presidential Decree (KEPRES) through the Ministry of Religion. This applies after the waiting period reaches the limit and then the customer is called to carry out the departure. After getting the remaining portion portion of the funds, only the initial deposit and the funds cannot be withdrawn unless the customer closes the BNI Baitullah IB Hasanah savings account. " (Interview on 28 February 2019).

The bank will continue to manage the hajj deposit funds and distribute it to financing department until it yields profit and certainly the income generated by the bank will be shared with the Ministry of Religion based on the procedure agreed by the owner of the fund. This is in accordance with sharia compliance in terms of the principle of 
universalism, which is the pilgrimage savings. Not only, that the account is managed by one of the parties namely the BNI Syariah KC Kendari bank but also by the Ministry of Religion as a Haj service provider, and the benefits obtained can be felt by all stakeholders. Bank BNI Syariah KC Kendari also has an automatic zakat feature as one of the instruments of implementing sharia compliance as described in interview as follows:

"... we will receive profit sharing or ratio. So the term is not interest huh. And the interest with this ratio is also different. Customer funds collected at the BNI Syariah KC Kendari bank will be channeled to productive business activities that are not contrary to Islamic principles. The management of these funds, of course, will benefit. Well, the profit will be shared with customers. From the profit sharing that we get, of course there is the obligation of zakat for customers. Bank BNI Syariah KC Kendari provides automatic zakat features. So, we can choose at the same time to cut the profit for zakat or not if we save in BNI Baitullah IB Hasanah hajj savings. " (Interview on 28 February 2019).

From the results of the interview, the hajj savings account at BNI Syariah Bank has implemented one of the sharia compliance instruments as referred to the principle of benefit (al-mashlahah), which is reflected in Islamic bank products in accordance with the principles and rules of Islamic muamalah, including the absence of elements usury as well as the application of property zakat. Baitullah BNI Hajj Savings Account at BNI Syariah $\mathrm{KC}$ Kendari Bank has also been guaranteed halal status of the savings products offered as described in the following interview results:

"As with Islamic banks in general, BNI Syariah KC Kendari Bank is also overseen by the Syariah Supervisory Board (DPS). All BNI Syariah Bank products including BNI Hajj Savings Baitullah IB Hasanah have been legally licensed by DPS. We also have internal oversight management, the compliance audit division, which oversees every operational activity, so that our savings are safe and our hearts are at peace because BNI Syariah Hajj Savings provide blessings because the management of funds is in accordance with sharia. God willing, our pilgrimage will be perfect with savings according to sharia. (Interview on 28 February 2019).

From the results of the above interview the authors concluded that Hasanah Hajj savings products at BNI Syariah KC Bank Kendari have met the sharia compliance element where the products offered in this case BNI Baitullah IB Hasanah Hajj Savings have received permission and approval from the Sharia Supervisory Board (DPS) and in its operational activities overseen by the management of internal supervision namely the Bank Syariah Syariah KC Standing Audit Division, Kendari. These findings were also reinforced based on the results of the author's documentation through on a deeper search of the company profile

\subsection{Analysis of Sharia Compliance BNI Hajj Savings Products}

Sharia Compliance (Shariah Compliance) has a legal basis, which is stated in the provisions of Article 2 paragraph (3) of PBI. 10/6/2008 (Amendment to PBI No. 9/19/PBI/ 2007) on the application of Shariah principles in fund-raising and fund-raising activities as well as the services of Shariah-compliant banks, the fulfillment of Shariah principles is fulfilled in accordance with Islamic principles. The principal provisions are justice and 
balance ('adl wa tawazun), health / safety (maslahah), Universality-Principle, and avoidance from gharar and riba.

The application of the principle of fairness and balance to BNI Baitullah IB Hasanah Hajj savings products at BNI Syariah KC Kendari Bank can be seen from the proportional profit sharing ratio of 5\% for customers and $95 \%$ for banks. This is based on the amount of the nominal balance in the customer's hajj savings account, the savings period, and the profit sharing ratio between the bank and the customer that has been determined through the equivalent rate. However, the distribution of profit sharing ratio in BNI Baitullah IB Hasanah Hajj savings products has been determined before the agreement of the Hajj savings customers with an adjusted number of decisions from the bank. This is done to minimize the risk of banks experiencing losses both internally and externally, and banks are required to return customer funds so that customers do not have any risk of depositing funds carried out at BNI Syariah KC Kendari Bank. The bank therefore sets the ratio range at the beginning of the agreement. This is related to governance, prudential principles and risk management of Islamic banks.

However, in the sharia principle the value of the profit sharing ratio is determined when there is discussion and agreement in a contract agreed by both parties. This means that the value of the ratio will appear when discussions begin between Sahibul Maal (owner of the fund) and Mudharib (manager of the fund). Because so far in some literature that discusses the mudharabah contract there is no theory that says one party can determine the value of the profit sharing ratio at the beginning before an agreement between Shahibul Maal (owner of the fund) and mudharib (fund manager). Of course this is contrary to the way banks apply the profit sharing value determination. From this explanation, we conclude that the Bank Syariah Syariah KC Kendari has not reflected the existence of the principle of justice and the principle of balance as a whole as referring to the concept of an agreement that prioritizes willingness or mutual love between the two parties.

In Shariah banking, this principle is reflected in Shariah-compliant products of Islamic banks that conform to Islamic principles and practices, including the absence of usury and the application of zakat on property. In the BNI Baitullah IB Hasanah Hajj savings product at BNI Syariah KC Kendari, this principle is reflected in the automatic zakat feature that can be selected by BNI Baitullah IB Hasanah Hajj savings customers, but this product is different from other savings products in raising BNI Syariah funds, because this savings is only needed to perform the pilgrimage and customers should not withdraw their savings funds because these funds are actually used to finance the implementation of the pilgrimage. In fact, it will automatically be used to finance the principal deposit (the cost of taking seat numbers) whose value is approximately 25 million rupiah. Judging from this difference, it can be concluded that the pilgrimage savings are not affected by the obligatory zakat, even though the savings have reached nishab and are stored for years during the waiting period of the prospective pilgrims. With proof, hajj savings cannot be withdrawn in cash according to the wishes of the customer. The benefits obtained by customers are only in the form of hajj implementation services, so that the savings are essentially to buy services, not to save cash.

In the BNI Baitullah IB Hasanah Hajj savings product, this principle is reflected in the mechanism of managing the Hajj savings fund where BNI Syariah KC Kendari uses a pool of fund approach in which all fund raising including pilgrimage savings funds are put together in a centralized system and then distributed to financing, such as mudharabah, 
musyarakah, and other sharia-compliant financing and this applies to all BNI Syariah offices. This principle is also reflected in the management of hajj funds collected by the Bank BNI Syariah KC Kendari where the benefits of managing hajj savings funds but can also be utilized by the Ministry of Religion as a provider of hajj services and the benefits obtained can be felt by all elements of interest.

Transactions whose objects are unclear, not owned, are not known to exist, or cannot be submitted at the time the transaction is carried out unless stipulated in Islamic law. Then gharar includes taking others' rights without permission, be it stealing, cheating, cheating or falsifying. BNI Baitullah IB Hasanah Hajj savings products are term deposits for the needs of the hajj. Savings funds are managed by Bank BNI Syariah based on a clear contract, namely wadiah and mudharabah, and are used for operational activities based on mudharabah mutlaqah with a predetermined profit sharing ratio at the beginning of opening an account.

BNI Baitullah IB Hasanah Hajj savings product is a term savings product that is used for hajj purposes. Therefore, the management of the hajj savings fund is based on the principle of mudharabah mutlaqah in this case the hajj savings customer does not require anything in the management of funds by the bank as long as its operations are in accordance with sharia principles. Related to the use of equivalent rates in the profit sharing calculation mechanism at BNI Syariah KC Kendari, equivalent instruments at Islamic banks are certainly different to the interest in conventional banks that compete very competitive in setting very attractive deposit rates in attracting prospective customers and sharing their profits determined at the beginning by calculating the amount of interest expense from funds held or borrowed and is greatly influenced by interest rates. The higher interest rates will be followed by rising deposit and loan interest rates. In its application, it is not allowed to equate the profit sharing with the equivalent rate, unless the equivalent rate is a past result.

\subsection{Analysis of BNI Baitullah IB Hasanah Hajj Savings Product Based on DSN-MUI Fatwa Review No. 02 / DSN-MU / IV / 2000 Concerning Savings}

BNI Hajj Baitullah IB Hasanah savings account is a time deposit where customers deposit their funds gradually both daily and monthly according to the wishes of the customers up to the Minimum Limit for Hajj Costs (ONH). However, this hajj savings product is different from other savings products at BNI Syariah KC Kendari Bank where the Hajj savings fund cannot be withdrawn according to the wishes of the customers, this is because the BNI Hajj Baitullah IB Hasanah savings account is only needed for the principal deposit to get the portion of departure and needs during running hajj. For this reason, this savings account is not facilitated with an ATM card as other savings at BNI Syariah Bank.

Bank BNI Syariah KC Kendari in this case as the recipient of funds deposited based on the results of the interview managing the funds for bank operational needs and the bank is responsible for the integrity of the funds. The bank is also entitled to the full right to profit from the use or utilization of Hajj savings funds. Hajj savings funds with a wadiah contract are not given for profit sharing, but are included in the pool of funds with a zero ratio (0), because the wadiah funding contributes to income, giving wadiah bonuses in accordance with discretionary bank policy and the bank has the right not to provide bonuses. 
Shariah BNI Shariah Bank KC Kendari used the gift of a trust fund in connection with the use of BNI Baitullah IB Hasanah pilgrimage fund. As was previously known, dhadah is a pledge whereby the bank in this case acts as a mudharib (fund manager) who can utilize the fund as per the bank's strategy and policy and the granting of bonuses is not promised but is voluntary.

If the customer uses the mudharabah contract, the customer acts as shahibul maal (owner of the funds) and the bank acts as the fund manager (mudharib). This can be seen from the management of savings funds managed by the mudharabah mutlaqah contract where the customer as the owner of the fund (shahibul maal) does not set certain conditions to the bank as the fund manager (mudharib) in using the hajj savings fund as capital in the bank's operational activities.

In its operations, Bank BNI Syariah KC Kendari uses the pool of fund approach in the management of bank fund resources. All fund products in the form of demand deposits, savings, deposits including hajj savings are put together as a whole for later investment or management through fund distribution products such as products based on profit sharing principles (mudharabah), products with the principle of buying and selling (murabahah), and others. Distribution of profits from the management of funds, BNI Syariah KC Kendari Bank is set for the profit sharing ratio for BNI Baitullah IB Hasanah customers, which is $5 \%$ for customers and $95 \%$ for banks. The percentage of this profit sharing ratio has been determined by the bank in the contract specimen at the time a customer opens a savings account.

Hajj funds become the largest channel of funds for fund management activities through financing, where funds under the mudharabah principle places banks as investment managers in the sense that all available funds must be channeled to the productive sector, so that the funds raised can generate income for banks and then the results of the revenue obtained will be shared with the owner of the fund. Even Islamic banks may not collect mudharabah funds if they cannot channel these funds to productive businesses, because whatever amount they get will still be shared with the owner of the funds.

Based on the results of the analysis, both product and management of BNI Baitullah IB Hasanah Hajj savings fund management at BNI Syariah KC Kendari Bank have fulfilled several instruments of sharia compliance should have a positive impact on the customers' trust that they pour in the form of savings, especially pilgrimage savings designated as costs go on pilgrimage. A purity of worship not only lies in the intention. Even if a hajj savings customer will not think about how much profit sharing he/she may obtain, the bank is still responsible to carry out the responsibility for the use of sharia labels on the bank.

\section{Conclusion}

Based on the results of research and discussion, it can be concluded that operationally the management of BNI Baitullah IB Hasanah Hajj savings products at BNI Syariah KC Bank Kendari has fulfilled sharia compliance instruments based on sharia principles or DSN-MUI Fatwa Number 02/DSN-MUI/IV/2000 about savings, both in terms of the contract used, transactions in progress and in other operations. BNI Hajj 
Savings Baitullah IB Hasanah has fulfilled the provisions of the principle of justice and balance (al 'adl wa tawazzun), the principle of benefit (al maslahah), the principle of universalism, as well it has avoided gharar and usury.

In terms of the use of the BNI Baitullah IB Hasanah wadiah saving contract using the yad dhamanah wadiah, the customer does not require anything to have their funds deposited. Judging from the use of the mudharabah contract for managing BNI Hajj Baitullah IB Hasanah, especially the use of mudlaabah mutlaqah contract, the hajj savings fund is managed based on bank strategies and policies without any specific restrictions and conditions on the part of the customer. The customer as the owner of the fund gets a profit sharing ratio of $5 \%$ for customers, while for BNI Syariah KC Kendari bank obtains $95 \%$.

\section{References}

[1] Tajudin MH, Mulazid AS. Pengaruh Promosi, Kepercayaan dan Kesadaran Merek terhadap Keputusan Nasabah Menggunakan Produk Tabungan Haji (Mabrur) Bank Syariah Mandiri Kcp. Sawangan Kota Depok. J Ekon Islam 2017;8. doi:http://doi.org/10.32678/ijei.v8i1.64.

[2] Mardian S. Tingkat Kepatuhan Syariah di Lembaga Keuangan Syariah. J Akunt Dan Keuang Islam 2015;3:57-68.

[3] Sugiyono. Metode Penelitian Bisnis. 2017. doi:10.1016/j.maturitas.2005.10.005.

[4] Triyuwono I. Akuntansi Syariah: Perspektif, Metodologi, dan Teori. Third. Jakarta: PT. Raja Grafindo Persada; 2012.

[5] Prastiwi IE. Pengaruh Persepsi Anggota Pada Sharia Compliance, Komitmen Agama dan Atribut Produk Islam Terhadap Customer's Trust Yang Berdampak Pada Keputusan Menggunakan Jasa Lembaga Keuangan Syariah (Studi Pada BMT Amanah Ummah Sukoharjo). J Ilm Ekon Islam 2018;4:28-40. doi:http://dx.doi.org/10.29040/jiei.v4i1.162.

[6] Kamla R. Critical insights into contemporary Islamic accounting. Crit Perspect Account 2009;20:921-32. doi:10.1016/j.cpa.2009.01.002.

[7] Birton MNA, Triyuwono I, Mulawarman AD, Rahman AF. Theory of Shariahization on Conceptual Accounting Framework: A Substantive Theory. Procedia - Soc Behav Sci 2015;211:723-30. doi:10.1016/j.sbspro.2015.11.093.

[8] Sjahdeini SR. Perbankan Syariah Produk-produk dan Aspek Hukumnya. Jakarta: PT Jakarta Agung Offset; 2010.

[9] Daulay AN. Faktor-Faktor yang Berhubungan dengan Perkembangan Produk Tabungan Haji Perbankan Syariah di Indonesia. Hum Falah 2017;4:105-36. 